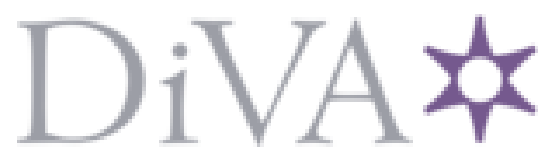

http://www.diva-portal.org

\title{
Postprint
}

This is the accepted version of a paper published in Educational gerontology. This paper has been peerreviewed but does not include the final publisher proof-corrections or journal pagination.

Citation for the original published paper (version of record):

Johansson, S., Ahnlund, P. [Year unknown!]

The Significance of Education for Establishment in the Care Sector:: Women and Men as Care

Workers with a Migrant Background..

Educational gerontology

http://dx.doi.org/10.1080/03601277.2013.848752

Access to the published version may require subscription.

N.B. When citing this work, cite the original published paper.

Permanent link to this version:

http://urn.kb.se/resolve?urn=urn:nbn:se:umu:diva-82729 
This article was downloaded by: [83.253.240.55]

On: 07 November 2013, At: 03: 36

Publisher: Routledge

Informa Ltd Registered in England and Wales Registered Number: 1072954 Registered office: Mortimer House, 37-41 Mortimer Street, London W1T 3J H, UK

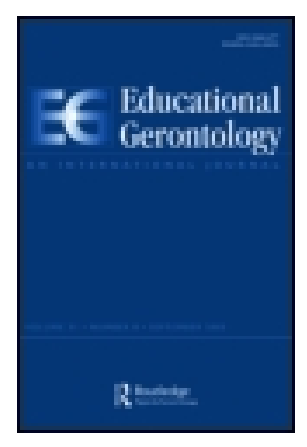

\title{
Educational Gerontology
}

Publication details, including instructions for authors and subscription information:

http:// www. tandfonline.com/loi/ uedg20

\section{The Significance of Education for Establishment in the Care Sector: Women and Men and Care Workers with a Migrant Background}

\author{
Stina J ohansson ${ }^{a} \&$ Petra Ahnlund ${ }^{\text {a }}$ \\ ${ }^{a}$ Department of Social Work, Umeå University, SE , Umeå SWEDEN \\ Accepted author version posted online: 11 Oct 2013.
}

To cite this article: Educational Gerontology (2013): The Significance of Education for Establishment in the Care Sector: Women and Men and Care Workers with a Migrant Background, Educational Gerontology

To link to this article: http:// dx. doi.org/ 10.1080/03601277.2013.848752

Disclaimer: This is a version of an unedited manuscript that has been accepted for publication. As a service to authors and researchers we are providing this version of the accepted manuscript (AM). Copyediting, typesetting, and review of the resulting proof will be undertaken on this manuscript before final publication of the Version of Record (VoR). During production and pre-press, errors may be discovered which could affect the content, and all legal disclaimers that apply to the journal relate to this version also.

\section{PLEASE SCROLL DOWN FOR ARTICLE}

Taylor \& Francis makes every effort to ensure the accuracy of all the information (the "Content") contained in the publications on our platform. However, Taylor \& Francis, our agents, and our licensors make no representations or warranties whatsoever as to the accuracy, completeness, or suitability for any purpose of the Content. Any opinions and views expressed in this publication are the opinions and views of the authors, and are not the views of or endorsed by Taylor \& Francis. The accuracy of the Content should not be relied upon and should be independently verified with primary sources of information. Taylor and Francis shall not be liable for any losses, actions, claims, proceedings, demands, costs, expenses, damages, and other liabilities whatsoever or howsoever caused arising directly or indirectly in connection with, in relation to or arising out of the use of the Content.

This article may be used for research, teaching, and private study purposes. Any substantial or systematic reproduction, redistribution, reselling, loan, sub-licensing, systematic supply, or distribution in any form to anyone is expressly forbidden. Terms \& Conditions of access and use can be found at http:// www.tandfonline.com/page/terms-and-conditions 


\title{
ACCEPTED MANUSCRIPT
}

\section{The significance of education for establishment in the care sector: Women and men and care workers with a migrant background}

\author{
Stina Johansson ${ }^{1}$, Petra Ahnlund ${ }^{1}$ \\ ${ }^{1}$ Department of Social Work, Umeå University, SE, Umeå SWEDEN \\ E-mail: Stina.johansson@socw.umu.se
}

\begin{abstract}
In this article we have followed women and men, with a Swedish or an immigrant background, which have completed the Upper Secondary Health Care Program. In which occupations do they work? Who employ them? Which target groups do they serve? Official statistics and survey data were used. The interaction between occupational structure and educational experiments was in focus. Gendered and cultural segregation and concentration within and between occupational groups were analysed in relation to defined targets groups and employer. We found that official statistics was not sensitive enough to capture the latent structure, while the survey uncovered signs of concentration and segregation of the care workers to certain occupations or target groups. Traditional career patterns were strengthened. Elderly care attracted women while mental care attracted men. We also found some unexpected paths among immigrant workers who chose more autonomous niches.
\end{abstract}

Occupations offer a structure to negotiate career patterns, and education is an important part of that negotiation. How do new demands for more formal qualifications meet a consolidated hierarchy of status labels and rooted ways of looking at skills? In Sweden, 


\section{ACCEPTED MANUSCRIPT}

the formal requirements for working in the care services, especially elderly care, have increased and it is important to know about the consequences of such a reform.

Health and social care services provided by Swedish government agencies are complex. Personnel require special qualifications. Questions of training and qualifications are pertinent topics that have been addressed by government agencies [see, for example, Gov. Bill 2005/06:115, The National Board of Health and Welfare (Socialstyrelsen 2002, 2004), The Swedish Association of Local Authorities (Svenska Kommunförbundet 2003)]. At present, the requirement for permanent employment in most municipalities is completion of the Upper Secondary Health Care Programme (USHCP) (Törnquist 2010). Completion of the USHCP qualifies an individual to work with a variety of target groups, for example elderly, disabled or mentally ill people. It qualifies them for employment as an auxiliary nurse (undersköterska), personal assistant (personlig assistent), mental care worker (mentalskötare), treatment assistant (behandlingsassistent), nursing assistant (vårdbiträde), care assistant (vårdare), and housing supporter (boendestödjare), and for employment in municipalities, county councils and private companies. Together, the listed occupations and target groups form what we call the target field of the USHCP, in registers called SSYK 513 (from now on here referred to as care workers). Completion of the USHCP is not an absolute requirement for work in that field but a recommendation. People who already work in one of these occupations can qualify for adult education that enables them to validate their skills and supplement what is missing for them to receive formal recognition of their competence. We have limited our study, however, to those who have taken the traditional schooling route.

\section{ACCEPTED MANUSCRIPT}




\section{ACCEPTED MANUSCRIPT}

Research shows that young people have problems establishing themselves in the labour market and that those with an immigrant background are more vulnerable than Swedish young people (Jonsson 2007, Knocke 2000). The care field offers then an opportunity for employment and the prospects for working in the USHCP's target field are good. In Sweden, the state guarantees universal access to care services and public services are widely used. The occupational field for care workers is relatively less well organized and has certain distinct advantages in workplace competition. Because it lacks a clear focus and a clearly established cognitive structure, the workers are free to move to available tasks (Abbott 1988, p 83).

The need for new recruitment in the elderly care sector will increase by about $50 \%$ up until 2030, which is a need for about 150,000 new employees (Kommunal 2010). Only about 3,400 students complete the USHCP each year, which indicates an enormous gap between future needs and the number of people with the formal education recommended for working with elderly people (Ahnlund and Johansson 2011).

The health and social care sector in Sweden has many traditionally gender-specific roles and a high percentage of immigrant workers. The proportion of people with an immigrant background is steadily increasing in the care and service occupations, and this is mostly in the elderly care services (SCB 2011a). The proportion of care workers born outside Europe has since 1998 gone from $5 \%$ to $15 \%$ of the total work force in the municipal health and care sectors (SCB 2011b). Among the 20,500 people recruited to 


\title{
ACCEPTED MANUSCRIPT
}

work in the municipal health and care sector in 2008, $20 \%$ were born outside Sweden, which represents more than a doubling in just over a decade (SKL 2009).

Gender segregation is traditional and today we can find that within SSYK 5132 (auxiliary nurses, nursing assistants) $93 \%$ are women and $7 \%$ are men. Whether the educational programme has rendered any changes in the gendered career paths has been one focus of our interest. In this article we will examine how men and women with a Swedish or an immigrant background establish themselves in the labour market after they graduating from the USHCP. Does completion of the USHCP form new career patterns or does the reform create new wine in old bottles?

\begin{abstract}
AIM
What significance has completion of the USHCP for work in the health and care sector for how young men and women with a Swedish or an immigrant background establishing themselves in the social care sector? Do women and men with a Swedish or immigrant background who have all passed the same recommended formal education strengthen already established patterns or are new patterns established? Of importance is that this sector is characterised by a large demand for labour and especially in elderly care. Will any status hierarchy related to target groups, occupation or employer arise? We will in this article map the distribution of men and women as well as Swedish natives and people with an immigrant background working with different target groups, in different caring occupations, and in different sectors (employers).
\end{abstract}




\section{ACCEPTED MANUSCRIPT}

\section{BACKGROUND - THE SWEDISH HEALTH AND CARE FIELD}

The occupational category "care workers" is not only the largest occupation in terms of total number of workers. The two largest subgroups in occupational field 5 are "Care assistant, personal assistant" and "Auxiliary nurse, nursing assistant". It is also the occupation in Sweden with the largest percentage of workers born outside the Nordic countries or outside the EU. Of the 151,800 people working in the occupational group "Care assistant, personal assistant" in 2010, 22 \% were born outside Sweden and of the 166,600 people working in the occupation group “Auxiliary nurse, nursing assistant”, 17 \% were not born in Sweden (SCB 2012).

The municipalities are ultimately responsible for ensuring that people living within its boundaries receive the support and assistance they need (SFS 2001:453) and also the largest employers when it comes to social care. Most personnel working with the elderly and disabled are employed by Swedish municipalities. (Kommunal 2008). The Swedish Municipal Workers' Union (ommunal) organizes most of the social care workers. Of their members, $64 \%$ are employed by municipalities, $15 \%$ work in private companies, and about $10 \%$ are employed by county councils. The remaining members are either employed by the Church, unemployed, students, or not in the work force due to parental leave or sick leave (ibid.). Among the registered nurses, $10 \%$ work in the private sector, $69 \%$ in county councils, and $20 \%$ in municipalities. The final $1 \%$ are state employees, for example, on the staff of a university (Vårdförbundet 2010).

\section{Women And Immigrants In Working Life}

\section{ACCEPTED MANUSCRIPT}




\section{ACCEPTED MANUSCRIPT}

Equal opportunities in working life (SFS 2008:567 and SOU 2010:60) is much about making it possible for everyone to advance vertically in the occupational hierarchy. Immigrant care workers are often reported to have limited chances to make a vertical career. Research also shows that in Sweden there are differences in working conditions for personnel born outside Sweden compared to Swedish-born staff in the health care sector (Kommunal 2011). For example, Swedish-born staff are more often permanently employed than personnel born outside Sweden. Studies with a qualitative approach show how immigrants working in elderly care are assigned characteristics (Gavanas 2013), which has consequences for how care work will be performed (Torres 2010).

Segregation between immigrants and Swedes began around 1970. Before that time, Sweden had been in need of a large number of immigrant workers, and in the 1960s participation in the labour force was the same for people born in Sweden and immigrants (Jonsson 2007). During the deep economic recession in the Swedish economy in 1991, unemployment became rampant and immigrants suffered the most (ibid.). By 1996, the proportion of immigrants in the labour market was only $75 \%$ of that of people born in Sweden, and more recent numbers are even worse. In 2003, the proportion was $60 \%$ participation for immigrants compared to $84 \%$ for Swedish-born workers (The Swedish

Integration Board 2004). A reverse pattern, however, has been seen in the care sector, and participation by people with an immigrant background in this field has been increasing over the past 25 years (SCB 2011a).

\section{SEGREGATION AND CONCENTRATION}

\section{ACCEPTED MANUSCRIPT}




\section{ACCEPTED MANUSCRIPT}

The labour market opens up possibilities for careers in many different directions. Karin Kullberg (2011), who studied gender issues in social worker careers, found that the traditional male social worker career went in a vertical direction and was concerned with acquiring power and superiority, but the modern male social worker career goes in a horizontal direction and is more concerned with creating an autonomous niche in which work is (or is made to be) exclusive, free, and independent. Kullberg argues that the niche is not just an expression of a new career pattern but that it also helps preserve a traditional sense of masculinity. The people who are the subject of our study are in occupations on an education level equivalent to or lower than that of social workers and represent a broad range of occupations. For our occupations there is no similar study.

The concept of segregation has been brought up in many of the debates about gender inequality. Segregation consists of both a horizontal dimension and a vertical dimension (Colgan and Tomlinson 1996). Horizontal segregation refers to positions on the same level of stratification, and vertical segregation refers to differences between those who do the more skilled and more responsible work.

A vertical career pattern is defined as a gradual take-over of higher responsibility, higher salary and leading positions, and is also related to power. In our study we can identify those who have completed their education and later graduated from university and are employed in an occupation classified at a higher level in the occupational register. A horizontal career is defined as a take-up of new work tasks while the person stays within the same occupation, which can imply learning of new work tasks, a 


\section{ACCEPTED MANUSCRIPT}

widening and sometimes deepening of professional knowledge, but an absence of traditional leading positions (see for example Hansen 2004). Blackburn \& Jarman (1997) suggest that 'segregation' must be separated conceptually from 'concentration.' The difference between those two concepts is that segregation refers to when men and women, or Swedish-born and immigrant workers, are intentionally employed in different occupations while concentration refers to the representation of any particular group within an occupation. Both concepts are relevant to our study group who, after having completed their education, were employed in different sectors and work with different target groups.

\section{RESEARCH REVIEW}

Two types of issues have been discussed in relation to care work and education. One is related to the status of care work and care workers. The other is related to the skills needed to perform care work.

\section{The Status Of Care Work}

In a survey of the status of occupations (Ulfsdotter Eriksson 2006, Svensson \& Ulfsdotter Eriksson 2009), the occupations in our study were labelled as having low status. For example, mid-wives (SSYK level 2) were in place 41; physiotherapists (SSYK level 3) in place 46, and registered nurses in place 48. The occupations on SSYK level 5 were labelled 78 (auxiliary nurse), 86 (personal assistant), and 87 (nursing assistant). To make the USHCP more popular to attend, an experiment was conducted to measure interest in the courses in "Protection and security", "Health and health promotion" and "Rescue and

\section{ACCEPTED MANUSCRIPT}




\section{ACCEPTED MANUSCRIPT}

emergency care". Health and health promotion was the course least applied for (Lindström 2008). This research provides a clear indication of the low status of care work, especially care of the elderly. Widding-Isaksen $(1994,2010)$ blames the low status on the intimate nature of the care work that often exceeds the limits of what is considered culturally acceptable. Dahle (1992) and Twigg (2000) also come to the same conclusion. Lindström (2008) shows that among those who have chosen "Health and health promotion", half of the students, and male students in particular, want to work within care of the disabled. No one in the study by Lindström mentioned elderly care as their desired area of employment.

\section{Caring Rationality And Education}

Traditionally, some types of care work, in particular elderly care, were performed by women who for a certain period had been housewives. Their qualifications have in the literature been described as particularly suitable for this kind of work. They show what could be called a 'caring rationality' (Wærness 1984), which has a high legitimacy in the workplace, and this is something that is appreciated among care managers (Ahnlund 2010, Törnquist 2010). Ahnlund and Johansson (2011) asked if immigrant care workers have perhaps replaced the housewives who no longer exist on a broad basis. Legitimacy at work places is an argument for the value of experience-based knowledge.

While cultural and institutional differences of care are evident, relational aspects of care are considered to be a core determinant of care quality. Immigrants are expected to possess such caring qualities. Older people and immigrant care workers believe that those 


\section{ACCEPTED MANUSCRIPT}

qualities provide a strong foundation from which the relationship can evolve (Walsh and Shutes 2013). It is easy to exploit such caring qualities. Torres $(2006,2010)$ describes attitudes towards immigrant women such as being listening and self-sacrificing people and how these attitudes affect staff relations in the work place. Support can be turned into suspicious attitudes and discrimination. Walsh and Shutes (2013) argue that an integrated effort is required around education and training, cultural and care orientation, alongside procedures and support for reporting and addressing discrimination.

\section{METHODS}

This study is based on an analysis of two data sets. First, register data from Statistics Sweden and second, a survey conducted in 2009/2010 in which those who had completed a USHCP in 1999 and 2004 participated $(n=1213)$.

We define vertical segregation according to the Standard for Swedish Occupational Classification (SSYK) levels of education. SSYK consists of 10 occupational areas. For our study four areas are relevant: area 1 (Legislators, senior government officials), area 2 (Professionals) area 3 (Technicians and associate professionals) and area 5 (Service workers and shop sales workers). On this scale, "5" represents the lowest level of education, " 3 " the middle, and " 2 " and " 1 " the highest levels of education.

\section{Register-Based Data}

The first set of data comes from official statistics from Statistic Sweden. To be able to follow up those who have completed the USHCP we followed those who had finished 


\section{ACCEPTED MANUSCRIPT}

school in 2000 to analyse what occupation they were in eight years later. They had all passed an educational programme given in Swedish, which guarantees that they all know Swedish and that the language cannot be a problem at work in the Swedish care sector. The following variables were retrieved from registers at Statistics Sweden: Gender, Swedish or immigrant background, Occupation: SSYK3 and 4.

Data on employment was retrieved for those who had graduated from a USHCP and found employment in the target field. We followed the same codes as in the occupational register where occupations are coded based on length of education, i.e. level 5 (Service, caring, and sales work that require an upper secondary education), level 3 (Occupations that require a shorter university education), and level 2 (Occupations for which a theoretical specialist competency is required). In our follow-up study, occupations on level 5 were separated from occupations on level 3 and level 2. How people moved from level 5 to levels 3 or 2 provided insight into vertical segregation and how it is related to gender and national origin.

Data on gender and Swedish or immigrant background was also collected from Statistics Sweden. $80 \%$ had a Swedish background. Of the $20 \%$ who had an immigrant background almost half came from eastern Europe (Europe outside EU27 and the Nordic countries) $46.5 \%, 30 \%$ came from Asia, $11 \%$ from Africa, $7.5 \%$ from South America, $2 \%$ from the Nordic countries (except Sweden) and EU27 (except the Nordic countries) respectively and only $1 \%$ from North America. One person came from the former Soviet Union. A person is defined as having an "immigrant background" if he or she was born

\section{ACCEPTED MANUSCRIPT}




\section{ACCEPTED MANUSCRIPT}

outside Sweden with two parents also born outside Sweden or born in Sweden with two parents born outside Sweden. In our analysis we follow this official definition. The country from which their family had migrated was not registered ${ }^{1}$. We also constructed the variable "country of birth" to determine if we could find any pattern related to the country that these people had migrated from. We further coded the study participants as being "born outside Europe", "born in Europe", or "Swedish born".

\section{Questionnaire Data}

The second source of data was a survey conducted in 2009/2010 that targeted those who had completed the USHCP. The survey was conducted in an iterative process with the authors and the contact person at Statistics Sweden, who was responsible for the sampling, distribution of the questionnaire, and registration and quality assurance of the material.

The population consisted of those who had completed a USHCP in Sweden in 1999 or $2004(\mathrm{n}=4428)$. Using stratified random sampling, 2,120 people were selected, of which 1,213 (57\%) participated. Due to the relatively low attrition rate, data was weighted. The following questionnaire items were used in the current study: Gender, Swedish or Immigrant background ${ }^{2}$, Questions: What is your main area of occupation? Answer options: auxiliary nurse, registered nurse, care assistant, psychiatric carer and other. Who is your employer? Answer options: municipality, county council, private company or

\footnotetext{
${ }^{1}$ This kind of question i difficult to handle for Swedish researchers as Swedish legislation prohibits the categorization of the population into ethnic groups for statistical purposes (SFS 1998:204).

${ }^{2}$ See footnote 1 .
} 


\section{ACCEPTED MANUSCRIPT}

other. In what main area do you work? Answer options: elderly care, care of people with disabilities/impairments, mental care, somatic care, primary care, school and other.

\section{Statistical Analyses}

For the descriptive analysis, data is presented in proportions or counts. For analyses of group differences, chi-square tests were performed using $p$-value $<0.05$. All analyses were performed separately for women and men. SPSS version 17.0 was used for the analyses.

\section{RESULTS}

\section{Distribution Of Care Workers In Relation To Occupation}

Our data shows that of those who completed their USHCP education in 2000 and were still employed 8 years later, $79 \%$ worked in one of the USHCP's target fields. Table 1 shows in which occupation these $79 \%$ were registered.

Our analysis showed that $75 \%$ of USHPC graduates work as "care workers" and $15 \%$ work as "registered nurses". If we also included the "midwives, nurses with special competence" category, we found that $93 \%$ of those working in the target field belonged to these three occupational groups. To be able to analyse the concentration within occupations among the care workers, we limited the analysis to include only these three occupational groups (Table 2).

Our analysis shows no large differences in distribution. Even when we used our constructed variable "country of birth" with the three alternatives born outside Europe, 


\section{ACCEPTED MANUSCRIPT}

born in Europe, or born in Sweden, no significant differences were found in the occupational groups mentioned above.

When we analysed the subgroups in "care workers", we found concentrations in some occupational groups but not in all. The largest concentration in that occupational group was found among the mental care staff where $31 \%$ of the men of Swedish origin worked, and this was almost twice as high compared to women. Women more often worked in the "auxiliary nurse, nursing assistant" occupation than men.

We found no significant differences in "registered nurses". Men with an immigrant background stand out. A comparatively high proportion of that small group worked as geriatric nurses, an occupation that does not attract many workers from the other groups (less than $10 \%$ ). However, the sample size for this group was small as only two people worked in geriatric care. This is probably due to random factors. A smaller proportion of men with an immigrant background worked as "other nurses", which may also be a random variation.

The proportion of men exceeded the proportion of women in the "midwives, nurses with special competence" group, which is one of the occupations with the highest demands as regards training. Many men specialised in "emergency care".

The data from Statistics Sweden regarding care workers with its subgroups is quite general but does provide some information about which occupational level those who 


\section{ACCEPTED MANUSCRIPT}

have completed the USHCP have entered. It does not, however, provide much information about which sector they are employed in or what kind of services they perform. For example, a nurse can be employed by a municipality or a county council and then work with different target groups such as the elderly or disabled people. They may work in hospitals, with people who suffer from somatic or mental diseases, or in primary care facilities. In Table 1, the occupational categories are clearly delineated but there might be some confusion about what these people really do at work. We therefore constructed a survey to be able to study their occupations more closely (Table 3).

$62 \%$ of those who consider themselves to be in the "health and social care workers" category worked as auxiliary nurses, and in this group there were variations according to both gender and national origin. Men of Swedish origin stood out and only $46 \%$ of them worked as auxiliary nurses. A higher proportion of men with a Swedish background work as care assistants and psychiatric carers compared to women as well as men with an immigrant background. Registered nurses were to a large extent people of Swedish origin. Among the registered nurses, the lowest proportion was men with an immigrant background. People with an immigrant background were more likely than those with a Swedish background to report that they worked in other sectors or in other occupations than the pre-defined alternatives in the questionnaire.

Finally we found a huge variation in occupational titles and workplaces that can be entered into after completing USHCP education. We have identified dental hygienists and dental nurses, managers (adminstrativ funktion), personal assistants, supervisors,

\section{ACCEPTED MANUSCRIPT}




\section{ACCEPTED MANUSCRIPT}

rehabilitation teachers/assistants, occupational therapists, and physiotherapists. This indicates that a wide range of professional opportunities are available for those who complete a USHCP. The diversity of occupational titles in each occupational group is a sign of a lack of clear focus.

\section{Distribution Of Care Workers In Relation To Employers}

Our interest was also related to employers and we tried to determine if there was any concentration or segregation related to gender or background. We initially show the proportion of those who report employment eight years after completing a USHCP, which includes not only those employed in the target field.

Table 4 shows that the most common employer for this group was, as expected, municipalities, which employed $43 \%$ of the respondents. We also found tendencies towards concentration by gender. There was a male concentration in companies in the private sector, and a female concentration in both municipalities and county councils. The tendency was even stronger in the care workers occupational group (Table 5).

In Table 5 we show a downward scale for employment in municipalities: from the highest level, consisting of women of Swedish origin to men with an immigrant background at the lowest. A concentration of men was found to be employed by companies in the private sector. $42 \%$ of the men with an immigrant background were found in the private sector. Another concentration was found among men who reported that they had another type of employment than those presented among the standardized response options. 


\section{ACCEPTED MANUSCRIPT}

Among the registered nurses, county councils were the most common employer. The most common groups working in the municipalities were men with an immigrant background and women with a Swedish background. There was a concentration of Swedish men in private companies, and no male registered nurses with an immigrant background worked in private companies.

\section{Distribution Of Care Workers In Relation To Target Groups}

Our survey included more detailed questions about the workplace and occupation of the respondents. The respondents were asked to define their target field. $80 \%$ of those who were employed defined themselves as working in the USHCP's target field; $82 \%$ of the women and $63 \%$ of the men. In the analysis related to the workplace, especially in relation to target groups, we asked the respondents what field they work in (Table 7).

Table 7 shows the target groups to which the services are delivered according to gender and national background. As shown, most people (43\%) worked in elderly care. Women worked in this field to a greater extent than men. Of the women, $49 \%$ with an immigrant background worked in elderly care compared to $45 \%$ of women with a Swedish background. A smaller proportion of men of Swedish origin (23\%) compared to men with an immigrant background (29\%) worked with elderly people. Within some fields we found a concentration according to gender. Mental care is mostly a male field, and in other fields we found concentrations by national background. A higher proportion of 


\section{ACCEPTED MANUSCRIPT}

people with a Swedish background were employed in the care of people with disabilities.

The proportion of people with a Swedish background was also high in bodily care.

The open response area in the questionnaire generated three main categories related to the target group. Most respondents reported that they were employed in hospitals $(\mathrm{n}=$ 81). A majority of men with an immigrant background (46\%) reported that they were employed in fields other than the pre-defined categories.

\section{SUMMARY AND DISCUSSION}

We have mapped the distribution of men and women as well as Swedish-born and people with a immigrant background, all with a completed USHCP, which target groups they work with, which caring occupations they belong to, and in which sectors (employers) they work.

Two contradictory results were found. The analysis of the commercially available material from Statistics Sweden shows that the USHCP provides for equal opportunities in career choices. No significant differences were found between "care workers" and "registered nurses". The chance to become a registered nurse is the same for both women and men and for Swedes and people with an immigrant background.

From our survey we found, on the contrary, that women were to a greater extent employed as auxiliary nurses than men. We also found that people with a Swedish 


\section{ACCEPTED MANUSCRIPT}

background chose to become registered nurses to a higher degree than those with an immigrant background, regardless of gender, see table 8 .

Segregation and concentration patterns appear in the results from our survey. Our conclusion is that official statistics only scrape the surface. The variety within the occupations disappeared as well as contradictory patterns related to status.

With our questionnaire we could concentrate on latent and hidden patterns in the data that are otherwise difficult to detect. When we focused on employers, we found some unexpected tendencies; see table 9 .

For the largest occupational group, care workers, men and women often follow different career paths, as do people with an immigrant background. Employment in private companies seems to be more of a male affair. This tendency becomes even clearer in relation to men with an immigrant background. The reason for this niching is something to follow up in future research. Is it a question of more autonomy, higher status or something else?

In our survey we had the opportunity to combine information about occupation and target groups, where we found some concentration and segregation patterns in relation to gender and background; see table 10. 


\section{ACCEPTED MANUSCRIPT}

Women, both Swedish and immigrants, were found to be more concentrated in elderly care. Men worked with more varied tasks and a wider variety of target groups. A large proportion of men with an immigrant background reported that they worked with "other".

\section{Implications For Research}

We have mapped patterns of concentration and segregation, but our mapping has led to more questions than answers and has implications for further research and practice.

Mapping segregation and concentration by surveying people who had completed the USHCP is a methodologically complex research task. We have found a need to assure the quality of official statistics. According to our analysis, the official statistics are too general. Occupational categories like "care workers" are too large and diverse to provide an understanding of the latent structures captured in the coarse-mesh net used. One can conclude that the caring sector is wide and inclusive and that the need for health and care workers is greater than the supply of trained care workers that the USHCP can satisfy (Ahnlund \& Johansson 2011). Our analysis has resulted in some findings with regard to inadequacies in the official statistics and about segregation and concentration within the labour market.

The staff in the "care workers" occupational group rated themselves in a variety of occupations. This shows that when the occupational title is not "protected" by professional or academic status, career development can take many different paths. This can create insecurity about what the work is about and about its societal value. The fact 


\section{ACCEPTED MANUSCRIPT}

that many of the respondents stated that they work in "other occupations" or "other companies" suggests a focus for future research. Researchers should include more varied response options so as not to miss any important information about, for example, which target groups might be covered by "others".

Sweden has a strong tradition of equal opportunities in the labour market. Our material has touched upon the fact that public and private companies attract women and men of Swedish and immigrant background differently. Further, knowledge is needed about why traditional and non-traditional jobs are distributed differently between men and women and between Swedish people and people with an immigrant background.

\section{\#ACKNOWLEDGEMENTS}

This study was financed by IFAU Institute for Evaluation of Labour Market and Education Policy, research grant 141/08. We would like to thank Professor Judith Phillips, University of Swansee, Ass. Director Deborah Chassler, School of Social Work, Boston University, Karina Nygren PhD, Umeå University for her comments and suggestions that helped us to significantly improve this paper.

\section{REFERENCES}

Abbott, A. (1988). The system of Professions. An Essay on the Division of Expert Labour. Chicago and London. The University of Chicago Press.

Ahnlund, P., \& Johansson, S. (2011). Omvårdnadsprogrammet: genomströmning, etableringsgrad och utbildningens relevans. IFAU Rapport 2011:19. 


\section{ACCEPTED MANUSCRIPT}

Ahnlund, P. (2010). Utbildning och mångfald. In S. Johansson (Ed.) Omsorg och mångfald. Malmö, Gleerups, 179-192.

Bill 2005/06:115, Regeringens proposition Nationell utvecklingsplan för vård och omsorg om äldre (National Development Plan for Care Work with Elderly People.).

Socialdepartementet, Stockholm.

Blackburn, R. M., \& Jarman, J. (1997). Occupational Gender Segregation. Social Research Update, Sociology at Surrey, University at Surrey.

Colgan, F, \&Tomlinson F. (1996) Women in Book Publishing - a "feminized" sector. In S. Ledwith, \& F. Colgan (eds.) Women in Organizations: Challenging Gender Politics. Macmillan.

Dahle, R. (1992). Profesjonell berøring. Sosiologi i dag, 4, 69-82.

Gavanas, A. (2013). Elderly care puzzles in Stockholm; strategies on formal and informal markets. Nordic Journal of Migration Research. 3, 63-71 DOI: 10.2478/v10202-0120016-6.

Hansen, H. K. (2004). A Study of Care Work with Elderly People. Danish National Report. Care Work in Europe. Current Understandings and Future Directions. Jonsson, O. J. (2007). The Farther They Come, the Harder They Fall?. In A. F. Heath \& S. Y. Cheung (Eds), Unequal Chances: Ethnic Minorities in Western Labour Markets. Oxford, University Press.

Knocke, W. (2000). Integration or Segregation? Immigrant Populations Facing the Labour Market in Sweden. Economic and Industrial Democracy, 3, 361-380. 


\section{ACCEPTED MANUSCRIPT}

Kommunal 2008-03-03. Vi i Kommunal. Available from:

http://www.kommunal.se/Kommunal/Om-Kommunal/Kommunal-i-siffror/Vi-i-

Kommunal/ [Last accessed 2013-03-13].

Kommunal. (2010). Välfärdstjänsternas framtida finansiering. 2010 24:7

Kommunal. (2011). Vem ska ta hand om mina gamla föräldrar när de blir gamla?. Art nr 9789171419682.

Kullberg, K. (2011). Socionomkarriärer. Om vägar genom yrkeslivet i en av välfärdsstatens nya professioner. Diss. Gothenburg, Department of Social Work. Lindström, K. (2008). Profiles in health care programme. An opportunity or an obstacle?. Malmö högskola, Lärarutbildningen.

SCB. (2011a). Tema: Utbildning. Etablering på arbetsmarknaden tre år efter gymnasieskolan. Statistics Sweden, Stockholm.

SCB. (2011b). Yrkesstrukturen i Sverige 2009. Yrkesregistret med yrkesstatistik. AM 33

SM 1101. Statistics Sweden, Stockholm.

SCB. (2012). Yrkesstrukturen i Sverige 2010. Yrkesregistret med yrkesstatistik. AM 33

SM 1201. Statistics Sweden, Stockholm.

SFS 1998:204, Personuppgiftslagen.

SFS. 2001:453, The Social Services Act.

SFS. 2008:567, The Swedish code of Statuses.

SKL. (2009). Aktuellt på äldreområdet 2008. Uppdaterad hösten 2009 Sveriges

kommuner och landsting

Socialstyrelsen. (2002). Kompetenskrav för personal inom vård och omsorg om äldre.

(Key Qualifications in Elderly Care.), Art. nr 2002-124-14, Stockholm, Socialstyrelsen. 


\section{ACCEPTED MANUSCRIPT}

Socialstyrelsen. (2004). Investera Nu! Handlingsplan för kompetensförsörjning inom vård och omsorg, (Invest now! Action Plan for Manpower Supply in the Care Services.) Art.nr: 2004-103-10, Stockholm, Socialstyrelsen.

SOU 2010:60 Utredningen om stärkt skydd mot åldersdiskriminering. (Commision on enhanced protection against age discrimination). Stockholm, 2010.

Svenska kommunförbundet. (2003). Aktuellt om äldreomsorgen. (Elderly Care Updated)

Svensson, L. G., \& Ulfsdotter Eriksson, Y. (2009). Yrkesstatus. Göteborgs universitet, Sociologiska institutionen, Forskningsrapport.

The National Board of Integration (2004). Rapport integration 2003, Stockholm Integrationsverket

Torres, S. (2006). Elderly Immigrants in Sweden: 'Otherness' Under Construction. Journal of Ethnic and Migration Studies, 32, 1341-1358.

DOI:10.1080/13691830600928730

Torres, S. (2010). Invandrarskap och tvärkulturella äldreomsorgsmöten. In S. Johansson (Ed.) Omsorg och mångfald. Malmö, Gleerups, 67-88.

Twigg, J. (2000). Bathing. The body and community care. London: Routledge.

Törnquist, A. (2010). Att leda mångfald. In S. Johansson (Ed.) Omsorg och mångfald. Malmö, Gleerups, 148-163.

Ulfsdotter Eriksson, Y. (2006). Yrke status och genus. En sociologisk studie om yrken på en segregerad arbetsmarknad. Göteborg, Göteborg Studies in Sociology, No 29. Vårdförbundet (2010). Vårdförbundet i siffror 2010. Röntgensjuksköterskor och sjuksköterskor. 


\section{ACCEPTED MANUSCRIPT}

Walsh, K. \& Shutes, I. (2013). Care relationships, quality of care and migrant workers.

Ageing and Society, 3. 393-420. DOI: 10.1017/S0144686X11001309

Widding-Isaksen, L. (994). Den tabubelagte kroppen. Kropp kjønn og tabuer i dagens

omsorgsarbeid. Bergen, Universitetet i Bergen.

Widding-Isaksen, L. (2010). Introduction. In L. Widding-Isaksen (Ed.) Global Care

Work. Gender and Migration in Nordic Societies. Lund, Nordic Academic Press.

Wærness, K. (1984). The rationality of caring. Economic and Industrial Democracy, 5, $185-211$. 


\section{ACCEPTED MANUSCRIPT}

Table 1. Occupation SSYK 2008 in target areas for those completed USHCP 2000, number and percent

\begin{tabular}{|c|c|c|c|c|c|c|c|c|c|c|c|}
\hline \multirow[b]{2}{*}{ SSYK } & & \multicolumn{4}{|c|}{ Women } & \multicolumn{4}{|c|}{ Men } & & \\
\hline & \multirow[t]{2}{*}{$\begin{array}{l}\text { Occupationa } \\
1 \text { title }\end{array}$} & \multicolumn{2}{|c|}{$\begin{array}{l}\text { Swedish } \\
\text { backgroun } \\
\text { d }\end{array}$} & \multicolumn{2}{|c|}{$\begin{array}{l}\text { Immigrant } \\
\text { backgroun } \\
\text { d }\end{array}$} & \multicolumn{2}{|c|}{$\begin{array}{l}\text { Swedish } \\
\text { backgroun } \\
\text { d }\end{array}$} & \multicolumn{2}{|c|}{$\begin{array}{l}\text { Immigrant } \\
\text { backgroun } \\
\text { d }\end{array}$} & \multicolumn{2}{|c|}{ Total } \\
\hline & & $\mathrm{n}$ & $\%$ & $\mathrm{~N}$ & $\%$ & $\mathrm{~N}$ & $\%$ & $\mathrm{~N}$ & $\%$ & $\mathrm{n}$ & $\%$ \\
\hline 122 & $\begin{array}{l}\text { Production } \\
\text { manager } \\
\text { and business } \\
\text { manager }\end{array}$ & 11 & 1 & 2 & 1 & 2 & 1,5 & 2 & 5 & 17 & 1 \\
\hline 223 & $\begin{array}{l}\text { Midwifes, } \\
\text { nurses with } \\
\text { special } \\
\text { competence }\end{array}$ & 33 & 3 & 6 & 2 & 11 & 9 & - & - & 50 & 3 \\
\hline 322 & $\begin{array}{l}\text { Occupationa } \\
1 \text { therapists, } \\
\text { Dental } \\
\text { Hygienist }\end{array}$ & 24 & 2 & 10 & 3 & - & - & 2 & 5 & 36 & 2 \\
\hline 323 & $\begin{array}{l}\text { Registered } \\
\text { nurses }\end{array}$ & 186 & 16 & 48 & 13 & 15 & 12,5 & 4 & 10 & 253 & 15 \\
\hline 331 & $\begin{array}{l}\text { Preschool } \\
\text { teacher and }\end{array}$ & 27 & 2 & 5 & 1 & 2 & 1,5 & - & - & 34 & 2 \\
\hline
\end{tabular}




\section{ACCEPTED MANUSCRIPT}

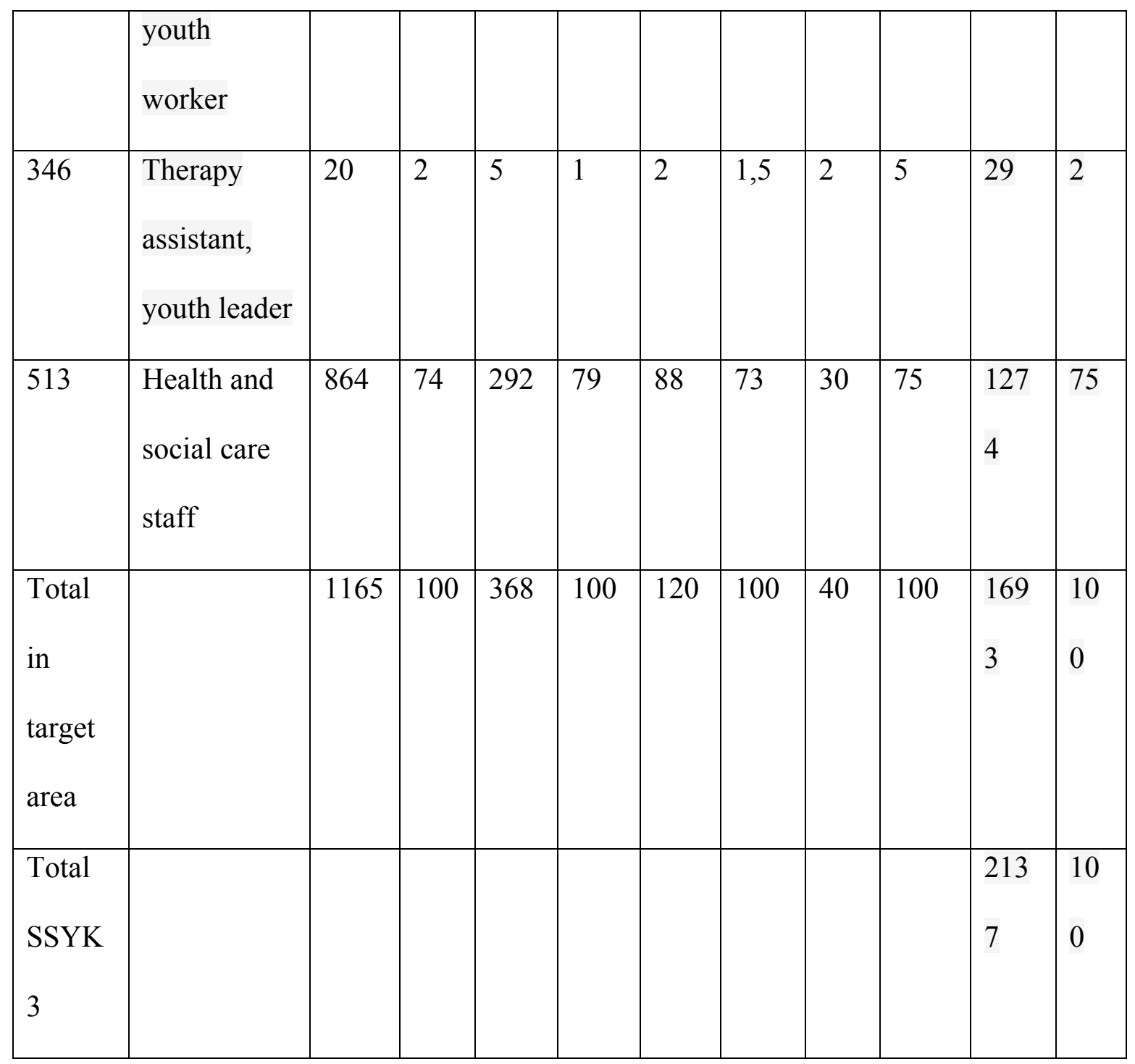




\section{ACCEPTED MANUSCRIPT}

Table 2. Occupation SSYK 2008 in target areas for those completed USHCP 2000, number and per cent

\begin{tabular}{|c|c|c|c|c|c|c|c|c|c|c|c|}
\hline \multirow{3}{*}{$\begin{array}{l}\text { SSY } \\
\text { K }\end{array}$} & \multirow{3}{*}{$\begin{array}{l}\text { Occupational } \\
\text { title }\end{array}$} & \multicolumn{4}{|c|}{ Women } & \multicolumn{4}{|c|}{ Men } & & \\
\hline & & \multicolumn{2}{|c|}{$\begin{array}{l}\text { Swedish } \\
\text { backgroun } \\
\text { d }\end{array}$} & \multicolumn{2}{|c|}{$\begin{array}{l}\text { Immigrant } \\
\text { backgroun } \\
\text { d }\end{array}$} & \multicolumn{2}{|c|}{$\begin{array}{l}\text { Swedish } \\
\text { backgroun } \\
\text { d }\end{array}$} & \multicolumn{2}{|c|}{$\begin{array}{l}\text { Immigrant } \\
\text { backgroun } \\
\text { d }\end{array}$} & \multicolumn{2}{|c|}{ Total } \\
\hline & & $\mathrm{N}$ & $\%$ & $\mathrm{~N}$ & $\%$ & $\mathrm{~N}$ & $\%$ & $\mathrm{~N}$ & $\%$ & $\mathrm{n}$ & $\%$ \\
\hline 223 & $\begin{array}{l}\text { Midwife, nurse } \\
\text { with special } \\
\text { competence }\end{array}$ & 33 & 66 & 6 & 12 & 11 & 22 & - & - & 50 & $\begin{array}{l}10 \\
0\end{array}$ \\
\hline 2231 & Midwife & 7 & & 2 & & - & & - & & 9 & \\
\hline 2232 & Managements & 1 & & - & & - & & - & & 1 & \\
\hline 2233 & $\begin{array}{l}\text { Emergency } \\
\text { nurse }\end{array}$ & 13 & & 2 & & 10 & & - & & 25 & \\
\hline 2234 & Pediatric nurse & 10 & & 1 & & 1 & & - & & 12 & \\
\hline 2235 & District nurse & 2 & & 1 & & - & & - & & 3 & \\
\hline 323 & Registered nurse & 186 & 73 & 48 & 19 & 15 & 6 & 4 & 2 & 253 & $\begin{array}{l}10 \\
0\end{array}$ \\
\hline
\end{tabular}




\section{ACCEPTED MANUSCRIPT}

\begin{tabular}{|c|c|c|c|c|c|c|c|c|c|c|c|}
\hline 3231 & $\begin{array}{l}\text { Nurse, } \\
\text { medicine/surger } \\
\text { y }\end{array}$ & 35 & 19 & 5 & 10 & 3 & 19 & - & - & 43 & \\
\hline 3233 & Geriatric nurse & 17 & 9 & 3 & 6 & 1 & 7 & 2 & 50 & 23 & \\
\hline 3234 & $\begin{array}{l}\text { Psychiatric } \\
\text { nurse }\end{array}$ & 4 & 2 & 4 & 8 & 1 & 7 & 1 & 25 & 10 & \\
\hline 3235 & Radiographer & - & - & 3 & 7 & 1 & 7 & - & - & 4 & \\
\hline 3239 & Other nurses & 130 & 70 & 33 & 69 & 9 & 60 & 1 & 25 & 173 & \\
\hline 513 & $\begin{array}{l}\text { Health and } \\
\text { social care staff }\end{array}$ & $862 *$ & 68 & $287^{*}$ & 23 & 88 & 7 & 30 & 2 & $\begin{array}{l}126 \\
7\end{array}$ & $\begin{array}{l}10 \\
0\end{array}$ \\
\hline 5131 & $\begin{array}{l}\text { Paediatric } \\
\text { nurse }\end{array}$ & 36 & 4 & 12 & 4 & 1 & 1 & 2 & 7 & 51 & \\
\hline 5132 & $\begin{array}{l}\text { Auxiliary } \\
\text { nurse, nursing } \\
\text { assistant }\end{array}$ & 590 & 68 & 193 & 67 & 44 & 50 & 16 & 53 & 843 & \\
\hline 5133 & $\begin{array}{l}\text { Care assistant, } \\
\text { personal } \\
\text { assistant }\end{array}$ & 127 & 15 & 43 & 15 & 15 & 17 & 6 & 20 & 191 & \\
\hline & Mental care & 97 & 11 & 18 & 6 & 27 & 31 & 4 & 14 & 146 & \\
\hline
\end{tabular}




\section{ACCEPTED MANUSCRIPT}

\begin{tabular}{|l|l|l|l|l|l|l|l|l|l|l|l|}
\hline 5134 & staff & & & & & & & & & & \\
\hline 5135 & Dental nurse & 8 & 1 & 20 & 7 & - & - & 1 & 3 & 29 & \\
\hline 3139 & $\begin{array}{l}\text { Other nursing } \\
\text { staff }\end{array}$ & 4 & - & 1 & - & 1 & 1 & 1 & 3 & 7 & \\
\hline & $\begin{array}{l}\text { Total all } \\
\text { occupation }\end{array}$ & 1081 & 69 & 341 & 22 & 114 & 7 & 34 & 2 & 157 & 10 \\
\end{tabular}

\footnotetext{
* In comparison to table 1, there are two persons less in 513 women with Swedish origin and five persons less in 513 women with an immigrant background in table 2 . Therefore the numbers in 513 are not the same in table 1 and 2.
} 


\section{ACCEPTED MANUSCRIPT}

Table 3. Occupation (in nursing and care), gender and Swedish/immigrant background.

Per cent. The results are significant on 0,001 level. $\mathrm{N}=2996$

\begin{tabular}{|l|l|l|l|l|l|}
\hline & \multicolumn{2}{|l|}{ Women } & \multicolumn{2}{l}{ Men } & \\
\cline { 2 - 6 } & Swedish & Immigrant & Swedish & Immigrant & Total \\
& background & background & background & background & \\
\hline Auxiliary & 63 & 61 & 46 & 65 & 62 \\
nurse & & & & & 21 \\
\hline Registered & 21 & 16 & 29 & 7 & 1,5 \\
\hline Carse & & & & 2 & 1,5 \\
\hline Psychiatric \\
carer
\end{tabular}

The results are based on weighted values. 


\section{ACCEPTED MANUSCRIPT}

Table 4. Employer for those working in the health and care sector 2008, per cent

\begin{tabular}{|l|l|l|l|l|l|}
\hline & \multicolumn{2}{l|}{ Women } & \multicolumn{2}{l|}{ Men } & \\
\hline & Swedish & Immigrant & Swedish & Immigrant \\
background & background & Total \\
& background & background & \\
\hline Municipality & 48 & 42 & 25 & 23 & 43 \\
\hline County council & 24 & 26 & 15 & 15 & 24 \\
\hline Companies non & 19 & 19 & 46 & 45 & 23 \\
public & & & & & \\
\hline Other & 8 & 13 & 14 & 17 & 10 \\
\hline$\%$ & 100 & 100 & 100 & 100 & 100 \\
\hline $\mathrm{Nr}$ & 1232 & 374 & 192 & 65 & 1863 \\
\hline
\end{tabular}

The results are based on weighted values. 


\section{ACCEPTED MANUSCRIPT}

Table 5. Employer for those working in SSYK 513 2008, per cent

\begin{tabular}{|l|l|l|l|l|l|}
\hline & \multicolumn{2}{l|}{ Women } & \multicolumn{2}{l|}{ Men } & \\
\hline & Swedish & Immigrant & Swedish & Immigrant \\
background & background & Total \\
background & background & \\
\hline Municipality & 66 & 56 & 53 & 31 & 62 \\
\hline County council & 15 & 18 & 15 & 19 & 16 \\
\hline Companies non & 14 & 14 & 21 & 42 & 15 \\
public & & & & & \\
\hline Other & 5 & 12 & 11 & 8 & 7 \\
\hline$\%$ & 100 & 100 & 100 & 100 & 100 \\
\hline $\mathrm{Nr}$ & 750 & 234 & 73 & 26 & 1083 \\
\hline
\end{tabular}

The results are based on weighted values. 


\section{ACCEPTED MANUSCRIPT}

Table 6. Employer for those working in SSYK 323 2008, per cent

\begin{tabular}{|l|l|l|l|l|l|}
\hline & \multicolumn{2}{l|}{ Women } & \multicolumn{2}{l|}{ Men } & \\
\hline & Swedish & Immigrant & Swedish & Immigrant \\
background & background & Total \\
& & background & background & \\
\hline Municipality & 10 & 2 & 7 & 25 & 9 \\
\hline County council & 76 & 87 & 72 & 75 & 78 \\
\hline Companies non & 8 & 8 & 14 & - & 9 \\
public & & & & & \\
\hline Other & 6 & 2 & 7 & - & 5 \\
\hline$\%$ & 100 & 100 & 100 & 100 & 100 \\
\hline $\mathrm{Nr}$ & 183 & 46 & 14 & 4 & 247 \\
\hline
\end{tabular}




\section{ACCEPTED MANUSCRIPT}

Table 7. Distribution in relation to target groups (in nursing and care), by gender and

Swedish/immigrant background. Per cent. The results are significant on 0,001 level

\begin{tabular}{|c|c|c|c|c|c|}
\hline & \multicolumn{2}{|l|}{ Women } & \multicolumn{2}{|l|}{ Men } & \multirow[b]{2}{*}{ Total } \\
\hline & $\begin{array}{l}\text { Swedish } \\
\text { backgrou } \\
\text { nd }\end{array}$ & $\begin{array}{l}\text { Immigrant } \\
\text { backgroun } \\
\text { d }\end{array}$ & $\begin{array}{l}\text { Swedish } \\
\text { backgroun } \\
\text { d }\end{array}$ & $\begin{array}{l}\text { Immigrant } \\
\text { backgroun } \\
\text { d }\end{array}$ & \\
\hline Elderly care & 45 & 49 & 23 & 29 & 43 \\
\hline $\begin{array}{l}\text { Persons with } \\
\text { disabilities/impairmen } \\
\text { ts }\end{array}$ & 16 & 6 & 15 & 7 & 14 \\
\hline Mental care & 3 & 4 & 13 & 10 & 4 \\
\hline Bodily care & 20 & 13 & 23 & 5 & 19 \\
\hline Primary care & 3 & 6 & 5 & - & 4 \\
\hline School & 1 & 1 & 2 & 3 & 1 \\
\hline Others & 12 & 21 & 19 & 46 & 15 \\
\hline Total \% & 100 & 100 & 100 & 100 & 100 \\
\hline Total nr & 2177 & 483 & 226 & 62 & 2948 \\
\hline
\end{tabular}

The results are based on weighted values. 


\section{ACCEPTED MANUSCRIPT}

Table 8. Concentration in relation to occupation. Summary of survey data

\begin{tabular}{|l|l|l|l|l|}
\hline \multirow{2}{*}{} & \multicolumn{2}{|l|}{ Women } & Men \\
\cline { 2 - 5 } & Swedish & Immigrant & Swedish & Immigrant \\
background & background & background & background \\
\hline Auxiliary nurse & $\mathrm{X}$ & $\mathrm{X}$ & & $\mathrm{X}$ \\
\hline Registered nurse & $\mathrm{X}$ & & $\mathrm{X}$ & \\
\hline Care assistant & & & $\mathrm{X}$ & \\
\hline Psychiatric carer & & & $\mathrm{X}$ & \\
\hline Others & & $\mathrm{X}$ & & $\mathrm{X}$ \\
\hline
\end{tabular}




\section{ACCEPTED MANUSCRIPT}

Table 9. Concentration in relation to employer (care workers). Summary of survey data

\begin{tabular}{|l|l|l|l|l|}
\hline \multirow{2}{*}{} & \multicolumn{2}{|l|}{ Women } & Men \\
\cline { 2 - 5 } & Swedish & Immigrant & Swedish & Immigrant \\
& background & background & background & background \\
\hline Municipality & $\mathrm{X}$ & $\mathrm{X}$ & $\mathrm{X}$ & \\
\hline County council & $\mathrm{X}$ & $\mathrm{X}$ & $\mathrm{X}$ & $\mathrm{X}$ \\
\hline Companies private & & & & $\mathrm{X}$ \\
\hline Others & & $\mathrm{X}$ & $\mathrm{X}$ & \\
\hline
\end{tabular}




\section{ACCEPTED MANUSCRIPT}

Table 10. Concentration in relation to targets groups. Summary of survey data

\begin{tabular}{|l|l|l|l|l|}
\hline \multirow{2}{*}{} & \multicolumn{2}{|l|}{ Women } & \multicolumn{2}{l|}{ Men } \\
\cline { 2 - 5 } & Swedish & Immigrant & Swedish & Immigrant \\
background & background & background & background \\
\hline Elderly care & $\mathrm{X}$ & $\mathrm{X}$ & & \\
\hline Disabilities/impairments & $\mathrm{X}$ & & $\mathrm{X}$ & \\
\hline Mental care & & & $\mathrm{X}$ & $\mathrm{X}$ \\
\hline Bodily care & $\mathrm{X}$ & & $\mathrm{X}$ & \\
\hline Primary care & $\mathrm{X}$ & $\mathrm{X}$ & $\mathrm{X}$ & \\
\hline Others & & & & $\mathrm{X}$ \\
\hline
\end{tabular}

